How to cite this article:

Idris, Z. (2020). Positioning Malaysia in the realm of global uncertainty: Analysing its concern and struggles of Pakatan Harapan government. Journal of International Studies, 16, 159-182. https://doi.org/10.32890/jis2020.16.10

\title{
Positioning Malaysia in the Realm of Global Uncertainty: Analysing Its Concern and Struggles of Pakatan Harapan Government
}

\author{
Zokhri Idris \\ Management and Science University, Malaysia \\ zokhri_idris@msu.edu.my
}

Received: 20/7/2020

Revised: 30/9/2020

Accepted: 2/11/2020

Published: 30/12/2020

\begin{abstract}
The US-China trade war has shackled the political, economic and social landscapes of many nations globally at varying degrees. While trade talks are still ongoing and President Trump has hinted at the possibility of an interim agreement, the prospects of an agreement between the two sides on a comprehensive US-China trade deal in the near-term remains uncertain. Several factors have placed Malaysia to be in a favorable position. One of these factors is that Malaysia continues to be an important geopolitical trading route. In addition to being considered an integral component to the production house of the global supply chain for finished products, Malaysia's economy is highly dependent on the movement of goods and global currency. Furthermore, Malaysia is also predominantly reliant on its trades with China. It is suggested that the trade protectionism in the U.S. has resulted into a slowdown of China's growth, whereby this has created a domino effect on the Malaysian economy. Moreover, the economic prospects of many countries have worsened due to the COVID-19 pandemic, which has led to a shutdown of major operations around the world that has disrupted global supply chains. Countries have employed inward strategies to alleviate national security and domestic economies, at the expense of the globalization process. Although the first wave of the virus has passed and world economies have started to recover, the global economy trajectory is still deemed ambiguous. China, which is a major hub for manufacturing, was heavily affected, and struggles to increase its GDP from 6.1 percent since the end of 2019. Due to the uncertainty on future prospects, the seventh Prime Minister, Dr. Mahathir Mohammed, had established three frameworks that would guide Malaysian foreign policy. Firstly, Malaysia will remain an active participant in all international organizations and treaties that it is a member of. Secondly, Malaysia will communicate its influence towards any decision-making processes in platforms where it is
\end{abstract}


not a member. Thirdly, Malaysia will align its aims to the Industrial Revolution 4.0 and the blue economy. Should this be the way forward from 2020 onwards, or would new strategies need to be crafted? What are the contemporary indicators that Malaysia should consider? Finally, what would be the ultimate message that would be delivered when Malaysia positions itself for its increasing potential in the near future? These questions will help guide this study in its examination of the feasibility of change in Continuity, as a strategy for Malaysian foreign policy in the near future.

Keywords: Change in Continuity, US-China Trade War, foreign policy, socio-economy, geoeconomy.

\section{Introduction}

\section{The Realm of Global Uncertainty}

Malaysia has continued to be triumphant at the global level due to its exemplary foreign policy. As a developing country, Malaysia's power projection was carried out via subtle diplomacy with other actors around the world. Similarly, when 'Pakatan Harapan' had come to power in a historic 2018 federal election, the challenges of the unprecedented coalition was not only to manage the trust of its electoral voters, but also to instill confidence amongst international players that the government would not deviate from its conventional diplomacy and multilateralism. This was not an easy task, considering the dynamics and uncertainties of global interaction. The global uncertainties that were faced by the 'Pakatan Harapan' government and disrupted the world order are; U.S. - China Economic Rivalry, and the COVID-19 pandemic.

\section{U.S. - China Economic Rivalry}

Since the Cold War, China has always been in the best interest of the U.S, when President Richard Nixon made a trip to Beijing in 1972. The prosperous state of China had attracted the U.S. to create a diplomatic relationship with the country. Prior to 1990, the U.S. had hoped that China will be more alike with respect to its economic terms for a liberal international system. After 20 years, at the end of 2010, China had emerged as the second largest economy while maintaining their single party authoritarianism. In 2019, China recorded its nominal GDP to be worth USD14.14 trillion (Silver, 2020). The differences of the political system between the two countries and its increasing nominal GDP has made U.S Government uneasy. Based on the book, Has China Won, Mahbubani suggested that the rivalry between the U.S. and China had stemmed from the different political ideology to champion world economy. He observes that "to most Americans, the idea that a free and open society like America, the world's strongest democracy, could lose a contest, against a closed communist society like China, is inconceivable" (Mahbubani, 2020: 9). Countries like Great Britain, Australia or any other democratic western block that rises as the world economy would not be an issue to the U.S Government. However, an authoritarian Chinese Communist Party (CCP), a ruling party that demonstrates excessive control over its citizen, 
would challenge democracy, which is viewed as a universal and acceptable political system around the world. China's rise to power would be a threat to the relevance and dominance of the western order.

As a result, several diplomatic frameworks have been crafted to undermine China's growth. During Obama's presidency, he approached a hallmark to China with a pivot, or rebalance to Asia, with Secretary Hillary Clinton as its main architect. When Trump won his presidency over Clinton, the president's efforts were claimed to have "fixed" the conflict between Washington and Beijing. However, the U.S Government did not address the root cause of the issue, but were merely focused on the technological and economical rivalry between the two countries. As a result, the level of tension and competitiveness had increased exponentially in a race to dominate the international system.

The U.S. - China trade war was said to have been caused when Trump attempted to impose demands upon China in its current trade negotiations. Kapustina et. al (2020) proposed that the factors which had led to the trade war was due to the U.S. insecurity on the rapid growth of China's economy. Some of the factors that had led to Trump's demand in the trade negotiations with China were as follows: a) to reduce the deficit of bilateral trade and increase the number of jobs in the country; b) to limit access of Chinese companies to American technologies and prevent digital modernization of the industry in the PRC; c) to prevent the growth of China's military strength; and d) to reduce the federal budget deficit (Ibid, 2020: 1).

In particular, the recent revival of the US-China trade war was due to U.S fear towards the Chinese networking infrastructure, Huawei. The U.S Government feared that China would use Huawei as a conduit to spy on U.S. operations and its people. Thus, President Trump had prohibited the firm to carry out any operations within the country and imposed a ban on Chinese products. He then revoked the Huawei brand, deferred 10 percent tariffs on USD300 billion of Chinese imports and urged China to purchase American agricultural goods. Not only that this impacted the economy of both countries, it also created a domino effect that greatly impacted other countries, like Malaysia. Malaysia's economic struggles stem from its exporting power in the global value chain. Malaysia is a major exporter of solar panels from the United States, and therefore, any tariff imposed by the U.S will greatly affect the economy of the country. With regards to China, Malaysian firms that are involved in the exports of components and materials will face a decline in trend. This is due to the flattening growth of China's GDP, which was up 6.1 percent in 2019, compared to 6.6 percent in 2018 (Tan, 2020).

The U.S. - China trade war escalated when Trump had aggressively increased tariffs on all Chinese imports and enforced a national emergency that prohibited Huawei from conducting its operations in the U.S. market. China lodged a complaint against the U.S. at the WTO over U.S. import duties as it violated the consensus reached by leaders of China and the U.S. in a meeting during the Osaka G20 Summit. China stated that it will defend its legal rights, in accordance with the WTO rules. China had commenced its third lawsuit against the U.S, however, U.S officials have accused China for the theft of intellectual property that is not 
covered by WTO rules. This has worsened the relationship between U.S. and China. Other member states are concerned with the prolonged trade war between the two countries as trade is established through the countries' alliance to the great powers.

The U.S. - China trade war has greatly affected Malaysia's economic trajectory. Mottain (2019) asserts if the trade war continues for another year, Malaysia may probably head into a recession. This is based on the consensus of consecutive negative GDP growth in two consecutive quarters, which would lead to an economic downturn. It is observed that Malaysia's trade volume has dropped remarkably by 10 percent -20 percent in the first half of 2020 (MATRADE, 2020). Lee (2018) further stated that full-fledged trade war may decrease the country's GDP growth to below 4 percent in 2021. As it is, Malaysia is one of the most trade-reliant economies globally, thus, it is vulnerable to any negative developments in the global trade scene.

Predictions made on the Chinese growth performance will also affect Malaysia's future economic prospect. Bloomberg economist, Maeva Cousin (2020) stated unfavorable conditions due to the decreasing China's export to the U.S. may fall on all embedded Asia's export supply chain, consisting of Taiwan, South Korea and China. It is predicted that the GDP of both China and the U.S. may decrease by 0.5 percent and 0.2 percent respectively, and would lead to a decline in global GDP output (Ibid, 2020). By mid-2021, it is predicted that the GDP will decline by 0.9 percent for China, 0.7 percent for the U.S. and 0.6 percent for the rest of the world (ibid, 2020). The global GDP loss of USD600 billion will subsequently impact the economies around the world.

Cheng (2019) suggested that the trade war may have a more damaging effect to Malaysia as Malaysia's small and open economy is deeply integrated with global supply chains and trade. Malaysia has a higher degree of exposure to the Chinese economy, whereby China continues to be Malaysia's largest trading partner and top source for tourism. Hence, there will be a significant decrease in Malaysian exports if there is any disruption to the Chinese supply chain. In addition, there might be opportunity for trade and investment diversion, for which U.S. importers will shun to replace Chinese goods that may later benefit other exporters in the region. However, it is uncertain that trade and investment diversion would overall offset the negative impact of the trade war on Malaysia. So far, Malaysia has not significantly benefitted from any 'trade diversion' by matching U.S. imports data with 7, 339 (2019:4) products listed in all three rounds of U.S. tariff. The Malaysian government is urged to be more proactive in its role when responding to the increased risk of trade protectionism.

\section{COVID-19}

The WHO's declaration of COVID-19 as a pandemic shows the intensity of the virus to change the world order. Based on the WHO report, 176 countries have been affected by the deadly virus since its discovery in early November. COVID-19 has reported nearly 28.6 
million cases with 919,706 death, as of September 12, 2020 (Worldometer, 2020). During the initial stages of spread, China had topped the charts with the highest number of cases, but their weathering strategies were very much questioned by international health authorities. China had reported its number of death against the total confirmed cases stand, which was 4,634 to 85,174 (as of September 12 $2^{\text {th }}, 2020$ ). Italy was least efficient in controlling the mass movements of its citizens that resulted in 35,597 death and 284,796 confirmed cases. The numbers are still increasing, despite passing the critical stage. U.S is now the most affected country after four months since COVID-19 was declared a pandemic, with a total of 6,636,247 reported cases and 197,421 death (as of September 12 $2^{\text {th }}, 2020$ ) (Worldometer, 2020).

During the early outbreak, people around the world, including Malaysia, were taking the pandemics lightly. Although announcements and enforcements were carried out by the authorities, the public's low observation of the rules and SOP (standard operating procedures) guidelines had increased the spread of the virus. The main reason for the wider spread of the virus was due to ignorance. It is only until one develops the symptoms of fever, cough, chest pain and shortness of breath, the public triggers the awareness of the mass to observe social distancing and movement restriction order. In the U.S, there are groups of people who still believe that COVID-19 is a normal influenza, and that the rules and guidelines should not compromise their freedom to move and work.

In Malaysia, the number of cases was originally derived from five clusters listed by the Health Ministry. Establishing the clusters was dependent on the Patient under Investigation (PUI) category. They involved; close contact, Tabligh Islamic group; influenza-like illness (ILI); severe acute respiratory infection (SARI); and humanitarian mission. Initially, Malaysia was exposed to the COVID-19 pandemic when two Malaysians had contracted the virus while they were in Singapore. At the same time, Malaysians who travelled to countries like Italy, China, Iran, South Korea and others were also exposed to the virus. Malaysia (as of September $12^{\text {th }}$ ) ranked $94^{\text {th }}$ in the world, and registered 182 deaths from 9,810 confirmed cases (Worldometer, 2020). The Malaysian government had declared the Movement of Control Order (MCO) that was implemented in phases. The current MCO is at phase four, i.e. Recovering Movement of Control Order (RMCO), where the impacts of the outbreak and the partial shutdown has clearly affected the economy, psychological, political and international relations.

Both the trade war and pandemic has changed the landscape of world politics. With the U.S being inward looking by slowing down from multilateral involvement, this allows more room for China's involvement in the world order. Due to the temporary halting of production in China, slower economic trajectory is predicted in other countries. ISIS asserts that the "trade wars can have wide-ranging impacts on the global economy, and that the policy uncertainty generated by the US-China tariff conflict will weigh heavily on investment, firms' financing cost, and financial market volatility" (Cheng et. al, 2019: 3). It can be concluded that these circumstances may cause uncertainties in the world. As a country that 
is dependent on import-export orientation, Malaysia struggles to find a sustainable foreign policy for the coming years.

Furthermore, Malaysia's political turmoil escalated during the COVID-19 pandemic due to the collapse of 'Pakatan Harapan' Government. The new coalition government might be bound to follow the framework set by the previous government. However, based on the arguments presented on the global uncertainty, there is ambiguity on the strategic policy to utilize the Change in Continuity Framework in the years to come.

Therefore, this study examines the feasibility of Change in Continuity Framework for Malaysia to address the global uncertainties caused by the trade war and pandemic. The scope of global uncertainty is measured by taking into consideration three accounts of the world order's reorientation, which are hyper-globalization process, reinstatement of nationalism and protectionism, and new wave of technology. The world order's reorientations are then used as measurement of contemporary uncertainty in the global politics to frame situational analysis as a methodology to examine the applicability of Malaysia's foreign policy network i.e., Change in Continuity. Situational analysis originated from business strategy framework, whereby internal and external factors were identified to examine the survival of a firm in the industry. By employing the same methodology, the paper highlights the three reorientations as factors that would determine the states' survival post COVID-19, and the US-China Trade War.

\section{Change in Continuity as Malaysia's Foreign Policy Framework}

Malaysia's foreign policy have shown consistency in its principles and alignment. The differences can only be determined on the degree of assertiveness of political leaders, especially the Prime Minister. According to Elina (2019), continuity can be identified in a five course direction on Malaysia's foreign policy namely; neutrality, non-aligned status and pragmatic dealings with major powers, ASEAN centrality, economy to trading policy, and championing Human Right issues. It is suggested that Malaysia had aligned with the international order due to the establishment of the country and construction of its foreign policy during the post-colonial era. However, during Mahathir Mohamed's premiership, Malaysia was focused on domestic developmental agenda and was critical to the Western agenda towards the developing countries and Muslim nation states. Within the regional setting, Mahathir had emphasized the self-reliability of East Asian region, in relation to the protection of its identity, security and economy. During his premiership (1982 - 2002), Mahathir was often viewed as the spokesperson on discrimination and inequalities towards developing countries, global south and Muslim countries. During the second cycle of his premiership in 2018, Mahathir reasserted his stand on the three causes he helped champion in 2002. Within the foreign policy framework published in 2018, Malaysia reaffirms its stand 'to practice the non-aligned policy and approach in its relations with the major powers, and cooperate with all like-minded countries to ensure countries are able to participate in global affairs on an equal basis without the pressure from any major power' (Ministry of Foreign Affairs, 2019: 27). 
However, based on the leaders' approach to Malaysia's foreign policy, policy analyst could not deny the pro-activeness of the leader in positioning Malaysia as a strong advocate to champion trade in the world. Malaysia's predecessor, Abdullah Badawi, was not alike Mahathir, where he only championed Islam Hadhari to the world, i.e. to project Malaysia as a progressive and fast developing Muslim country, contrary to the conservative Muslim countries. Subsequently, Prime Minister Najib Abdul Razak was focused on neutrality and openness to all countries, while the economy and FDI was his primary consideration. The assertiveness displayed by Malaysia was much lower during Abdullah Badawi premiership due to internal political bickering that had deviated the focus of the people, as proposed by Khalid (2009: 307). Moreover, she highlighted the significant increase of political bickering from Abdullah's time to Najib, which had urged Najib's administration 'to review its relations with selected countries and regions of the world to meet up the challenges from an increasingly volatile international political and economic environment' (ibid, 2009: 308).

The two scenarios that had undoubtedly changed the world order suggest that Malaysia must be prepared for a foreign policy renewal. The current standing of Malaysia's foreign policy is based on the framework laid out by the then Prime Minister Mahathir Mohamad, during his speech at the 2018 United Nations General Assembly (New Straits Times, 2018). His speech introduced the Foreign Policy Framework of The New Malaysia: Change in Continuity, which was released by the Ministry of Foreign Affairs in June 2019. The Policy Framework highlighted five tenets in order for Malaysia to function as a rising nation within the international sphere, which are: a) basic elements of foreign policy remain unchanged under New Malaysia; b) Malaysia continues to pursue independent, principled and pragmatic foreign policy; c) Malaysia believes in maintaining friendly relations with all countries and in peaceful resolution on disputes based on international law and norms; d) Malaysia reserves the right to express its opinions, protestations against injustices, oppression and crimes against humanity; and e) Malaysia remains steadfast in pursuing its foreign policy goals based on the principles of justice and fairness.

a) Basic elements of foreign policy remain unchanged under New Malaysia. Physical survival of a state is dependent on governance and citizens of the country. National interest remains the top priority of any foreign policy, including Malaysia. Malaysia upholds the existing principles of neutrality and friendship to all countries. Bilateral and multilateral settings remain unaltered as modern diplomacy requires both to be strengthened simultaneously. This includes Malaysia's membership in the United Nations (UN), Asia-Europe Meeting (ASEM), Organisation of Islamic Countries (OIC), Non-Alligned Movement (NAM), Association of Southeast Asia Nations (ASEAN), Forum for East Asia-Latin America Cooperation, Asia Cooperation Dialogue (ACD), Commonwealth, Developing Eight (D8), Group Seventy-Seven(G77), Asia-Middle East Dialogue (AMED), Indian Ocean Rim Association (IORA) and Group Fifteen (G15). 
During the Prime Minister's official visit to Tokyo, he reassured that Malaysia would not deviate from the basic and conventional foreign policies. In his speech, he mentioned that 'although our government has changed, our policies towards other countries are still the same. We want to be friendly with all the countries of the world irrespective of ideologies, and we want to ensure that we can keep on trading and have access to all the markets of the world [...] because we depend on trade in order to grow our country' (Prime Minister's Office, 2018)

b) Malaysia continues to pursue an independent, principled, and pragmatic foreign policy.

The fundamental principles of Malaysia's Foreign Policy have always been consistent since its establishment in 1963. Malaysia is an independent country that upholds the principles of neutrality, peace, freedom and nonalignment to specific country. Malaysia's foreign policy is carried out pragmatically, as manifested.

In his speech to the UN General Assembly, Prime Minister Mahathir assured Malaysia's adherence to the common principles and practice established in the international treaties and agreements. The new government would commit to ratify UN's initiatives and treaties as a tangible support to the organization. In his speech, during the $73^{\text {rd }}$ UNGA, he stated that:

"The new Malaysia will firmly espouse the principles promoted by the UN in our international engagements. These include the principles of truth, human rights, the rule of law, justice, fairness, responsibility and accountability, as well as sustainability. It is within this context that the new government of Malaysia has pledged to ratify all remaining core UN instruments related to the protection of human rights. It will not be easy for us because Malaysia is multi-ethnic, multireligious, multicultural and multilingual. We will accord space and time for all to deliberate and to decide freely based on democracy" (New Straits Times, 2018).

Prime Minister Mahathir Mohamed reaffirmed Malaysia's support to "galvanizing multilateral efforts for poverty eradication, quality education, climate action and inclusion". Despite Malaysia's criticism to the one-sidedness of the UN, Malaysia has continued to establish its policies, in line with democracy, international trade, multilateralism and capitalism. In the end of his speech, during the $74^{\text {th }}$ UNGA, Mahathir concluded by stating;

"The UN has failed in protecting the poor from the scourge of war. But in other fields it has done much better. It has contributed to better health, to alleviating the sufferings of some of the poor and the needy. It does provide a degree of security and stability in places plagued by internal conflicts. It can do more. But it is short of funds. Countries including the very rich are not paying their 
dues. It is shameful. We need to support the UN even though it has failed to banish wars. Its work on health, education and social security to make the UN worth having." (New Straits Times, 2019).

c) Malaysia believes in maintaining friendly relations with all countries and in peaceful resolution of disputes based on international law and norms.

Malaysia has deployed its armed forces for peace missions abroad. Amongst the deployments involved are the genocide crises of Bosnia-Herzegovina, Congo and Syria. In the initial stages of foreign policy, Malaysia helped solve confrontations between Indonesia and The Philippines by establishing (MAPHILINDO). Although 'Pakatan Harapan' had governed the country for less than 24 months, there was no policy endorsed that would bypass resolution of disputes based on international law and norms.

d) Malaysia reserves the right to express its opinions, protestations against injustice, oppression and crimes against humanity.

As an independent and principled nation, Malaysia reserves the right to express opinions. Malaysia had objected the apartheid system (a blatant discrimination based on race) and communicated its stand at the world stage. During the premiership of Mahathir Mohamed, Malaysia had also expressed the unfair treatment of the Western blocs towards developing and Muslim countries. Its non-recognition of the Israeli occupation in Palestine had resulted into a cease of all diplomatic relations with Tel Aviv. During his second tenure as the Prime Minister, Mahathir Mohamed expressed his opinion on the injustices of the world system. In the 2019 UNGA, Mahathir Mohamed had highlighted the unfairness of UN's veto system, as it was a one-sided system that favored the major powers, at the expense of the developing countries. Mahathir had called for a UN Reform on veto power, which received support from all major developing countries around the world.

These were considered strong criticism to the world system that was dominated by the western block. However, Malaysia had utilized valid platforms to express its opinions.

e) Malaysia remains steadfast in pursuing its foreign policy goals based on the principles of justice and fairness.

The moral compass of justice and fairness are considered when establishing Malaysia's foreign policies. Justice and fairness are upheld across countries and organizations, as can be observed for regional issues on refugees and transboundary haze. With regards to China's expansion into the South China Sea, Malaysia has stood firm in its stance through regional 
setting against China's actions. Malaysia's resentment was communicated after taking into consideration of the legal aspect of the United Nations Convention and Law of the Sea (UNCLOS). In relation to the 'Pakatan Harapan' Government's response towards the BRI, it is suggested that the BRI does not adversely impact the economy and its citizens. Bergers (2018) proposed that the PH leaders, especially Prime Minister Mahathir, have consistently argued that "they were not against China, but only the problematic projects, in which the primary responsibility laid in the Najib premiership, not China". Elements of fraud that were detected during Najib's premiership when signing the deal had urged 'Pakatan Harapan' to further scrutinize and review the nine projects under the BRI.

Therefore, change in continuity requires the establishment of certain modifications to meet the demand of the contemporary circumstance. Leifer (1989) defined change as 'the departure from the norm'. As subsequently argued in this study, three re-orientations are employed to examine the situations that stemmed in the last two years. The world politics of today is relatively different from what it was before. Theorists of change argues that changes may differ, regardless of the situation. By exploring the paradox of managing continuity and change, researchers have defined the types of change, and how the elements of continuity can be a balancing act when making changes (Nasim \& Sushil 2011). The study proved that, when acknowledging theories of change, it must be a balancing act between advocating change in an organization while maintaining existing 'as-is' roles, and the functions of the administration. Change is inevitable, and structure should be reengineered with a degree of continuity.

Based on the conclusions presented by Leifer (1989), and Nasim and Sushil (2011), Change in Continuity posits a modification of methodologies and implementation, without altering its basic fundamentals. In other words, the tactics and strategies employed may be different across time, but the principles of Malaysia's foreign policy remains unaltered.

For a developing country like Malaysia, change in continuity can be observed by restoring the trust of the international and local community when projecting Malaysia's Foreign Policy. The projection includes consistency and sustainability of Malaysia's philosophy and belief when interacting with international actors and countries. Despite the rhetoric of New Malaysia by the new government, Malaysia has been able to convince the world that the country is able and willing to amend its foreign policy when required. Malaysia aspires to gain the trust of the global political players. Despite the change of government and civil servants, Malaysia's objectives remains unchanged.

Malaysia's Foreign Policy projects the behavioural response as follow:

i. Malaysia remains as an active participant in all platforms for which Malaysia is a member; 
ii. Malaysia communicates its influence towards any decision-making process in platforms, where Malaysia is not a member;

iii. Malaysia aligns with the increasing penetration of IR 4.0 and blue economy.

\section{Re-orientation of the World Order}

While Malaysia is expecting for these projections to remain undisrupted for the next couple of years, strategists and foreign policy experts would need to consider the contemporary world order, particularly the ongoing U.S. - China Trade War and the COVID-19 pandemic. Discussion on the world order are actively debated as the situations are still developing, however, the basic tenets are identified and highlighted, which are the rise of nationalism and protectionism, reversal of hyper-globalization process and emergence of new wave technology.

\section{a) Reversal of Hyper-Globalization Process}

Hyper-globalization is used to describe the depth integration of politics, social and economy among actors. The collapse of the Berlin Wall in 1990 ended decades of rivalry between liberal democracy and communism. Since then, globalization has integrated deeper with new actors (including NGOs) from different levels. The COVID-19 pandemic originated from the second largest economic power, China. Wuhan, as a big economic city, had created a domino effect to its surrounding cities and countries, like South Korea and Japan. Countries became inward thinking, and were focused on internal measurement to address the spread of the COVID-19 virus.

However, the rivalry between great powers is still ongoing, and will likely continue in the future. The intensity of the rivalry would be lower due to inward looking measures from governments. This can be clearly illustrated during Trump's presidency when Washington adhered to inward looking, rather than being a multilateral country. Trump conveyed his antiglobalism belief during the UN General Assembly by initiating a trade war with China. The aftermath of the November 2020 election is yet to be seen, but if President Trump triumphs for his second term, the U.S. will likely to be inward looking country. The possibility of the COVID-19 pandemic to become a world conflict is low. The great influenza during 19181919 did not result into the World War 2. Therefore, the Thucydides Trap would not be applicable to the COVID-19 pandemic.

Nevertheless, there are various negative impacts caused by the COVID-19 and US-China Trade War to the world supply chain system. Although manufacturing is cheap and efficient, the global shutdown and recurring lockdowns have affected China's ability to continue being the world's supplier (Andrews, 2020). As a pushback from the reversal demands of international trade, China's new economic plan aims to utilize its internal market. China could not enjoy the benefits of international trade as before, and started to look inward, by following the footsteps the U.S Government. China's new economic plan of building up 
its domestic market to reduce China's reliance on export has the risk of being undermined by the lack of purchasing power among the people. In May, President Xi had stated that "a new dual circulation plan focusing more on the domestic market, would be China's strategic approach to surviving and thriving in an increasingly unstable and hostile world" (He, 2020).

However, the pandemic had required stricter controls over the movement of people and economy. For example, the Johor-Singapore Causeway and the Second Link were closed, resulting to hundreds of Malaysians to be stranded in Singapore. Malaysians, who were working in Singapore, feared for their employment prospects, should the Movement Control Order (MCO) be further extended. Meanwhile, the conflict among great powers and states still exist. At the moment, Malaysia is still not prepared to open its international borders. Malaysia's tourism is currently depending on its domestic supply and demands. The industry was reported to be badly affected, but has shown a recovery process due to the support from the local market. In 2019, Chinese tourists were the third largest number of tourist to have visited the country, with 2.41 millions after Singapore (7.8 million) and Indonesia (2.7 million) (Povera \& Goh, 2020). As a result, this has generated the local market, but the dependence on international tourists has tremendously affect Malaysia's tourism industry.

The COVID-19 pandemic will instill greater dependence on state individualism and selfcentered behavior. Consistent self-centered behavior will undermine the globalization process. Emanuel Macron of France, although he is an advocate for free trade, has indicated that globalization is currently under crisis, following a high reversal of trade volume between countries.

\section{b) Reinstatement of Nationalism and Protectionism.}

This closely relates to Re-orientation 1 . State leaders have centered their focus to the internal health crisis. Governments of South Korea, New Zealand, Singapore and Malaysia are examples of countries that have increased communication with the public. The transparency of national government is observed to be at its peak in each country. Any action and omission has been scrutinized by the public. For instance, the health care system has been the top priority of nation states, and has been subjected to the scrutiny of local citizens. National governments have been focusing on their health care system to avoid uproar from the people. Regardless of the positive and negative perceptions of the people, nationalism has received the limelight during this crises. It is observed that Malaysia's political turmoil has been gaining less attention since the Second Wave of the COVID-19. German chancellor, Angela Merkel, had banned exports of protective medical equipment to neighboring countries, like Austria and Switzerland (Vogel, 2020). This measure had created an uneasy diplomatic relation between the countries. German Interior Minister, Horst Seehofer, states that the COVID-19 pandemic should no longer be seen as a health crisis, but should be considered a national crisis (ibid, 2020). COVID-19 has become a national and international agenda throughout 2020 . 
Before the COVID-19 outbreak, the U.S and the U.K had adopted protectionism mechanisms for their countries. However, the pandemic has shown that the U.S is at its highest volume of nationalism and protectionism with the Declaration of National Emergency, after a gay pride movement in Miami had received many backlashes. Boris Johnson has declared 'virtual' lockdown (closing all non-essential shops, banning meetings of more than two people and requiring people to stay in their homes, except for trips for food or medicine) days after a Stereophonic Gig concert was held in Cardiff. The Tokyo Olympics has been rescheduled to 2021. The cancellation of mass gathering allows protectionism to be employed throughout the world.

State nationalism coincides with Government's populism. Malaysia's 'Pakatan Nasional' government was sworn in with the mixed reaction by its people. Anti-establishments argue that 'Pakatan Nasional' is not a legitimate entity as their establishment was not through the general election. Political actors complimented Malaysia's health governance in its fight against the pandemic. The new Prime Minister had released economic stimulation packages that is aimed at assisting the people who have been economically affected. The first, announced on February $26^{\text {th, }} 2020$, listed a comprehensive package to health workers who served as front liners during the pandemic, followed by PRIHATIN, which is a more comprehensive cash distributions for the B40 and M40 (Jabatan Perdana Menteri, 2020) citizens. Household income and single earning individuals were given RM 1,000 to 1,600 and RM250 to RM500 respectively, based on their projected income. With regards to social mobility, the Honorable Minister of Defence Ismail Sabri, had frequently communicated to the public on the Movement Control Order (MCO), mobilization of the mass, as well as the presence of the military. The MCO was regulated jointly with the Royal Malaysian Army and the Royal Police of Malaysia. There was no miscommunication between executive arms, political actors and the civil service during the first two weeks of the MCO. It was acknowledged that political sentiment had reduced to a considerable level in social media as people were more concerned with issues relating to health, MCO campaign, and Stimulation Package.

It is difficult to conclude on the accurate consequences that may have stemmed from the US-China Trade War, in relation to the rise of protectionism and populism. Nevertheless, the emergence of COVID-19 in the midst of the trade war had multiplied the intensity of states' protectionism and populism.

\section{c) New Wave of Technology}

Face to face interaction happens on a new dimension, and involves virtual meetings. Schools and universities around the world had adopted online learning. Firms' BAU (business as usual) was strongly supported by Zoom, Space, and Padlet-based meetings. Consumers began to utilize e-wallet, and conducted online shopping to maintain social distancing. Although buying at food stores is still a lifestyle, it is observed that Food Panda and Grab Food were fully operational to meet the demands of paranoid consumers that were not allowed to leave their residence. This indicates that technology had not only created an easier life where things get done mostly over the line, but societies have become virtually aligned, and it has become the norm. 
It is important to note that the technological interaction were only in high demand in big cities. Rural areas found this interaction new and too sophisticated. For example, the citizens of Penang still preferred to shop at the market, despite being warned by authorities. Nevertheless, COVID-19 gives an unplanned scenario for people to look further into $21^{\text {st }}$ century interaction. On a global setting, the inequality to technological access will further divide the societies and countries that do not have internet connectivity. Japan, South Korea and Israel would weather the pandemic with technological assistance and would easily be back on track, leaving third world blocks to remain struggling from the slowdown of economic activities.

The US - China Trade War had stemmed due to the fight for ownership of 5G telecommunication technology. The U.S could not catch up to its adversary in championing $5 \mathrm{G}$, since Huawei was rapidly establishing $5 \mathrm{G}$ utilization.

\section{Framework Application into Three Orientation of the World Order}

The key questions identified in this study stem from the aspects of practicality and sustainability. This study aims to answer the following questions; is the framework of Change in Continuity practical to weather three re-orientation of the world order?, and is the framework of Change in Continuity sustainable to weather three orientation of the world order?

Pragmatism requires a degree of flexibility when crafting foreign policy that would suit the current changes in the world order. Based on the three re-orientations discussed above, Malaysia's foreign policy needs to fit rightly into the orientation, when forwarding national interest. The national interest must be focused on the survival of the government and its people, hence, pragmatism will require adaptability of Change in Continuity framework, pursuant to a post-Covid orientation.

Sustainability refers to the consistency of foreign policy projection. Good policy requires sustainability of power projection throughout the changes of the world order. Creativity and modification of such projection are allowed, as long as the goals could be achieved through the implementation of such policies. Therefore, change in continuity framework offers a consistent fundamentals to Malaysia's foreign policy.

It has been argued that nationalism and protectionism will be the ongoing trend post COVID-19. Harvard researchers predicted that the pandemic will take approximately two years before it could be fully managed by the world healthcare system. Countries have closed their boarders and economies to be protectionist. However, it should be noted that nationalism and protectionism should not be deemed as the end goal after the pandemics. These are just temporary measures to slow down the virus, and are not considered the defining strategies implemented by countries for the long term. Therefore, it should be coined as forward looking nationalism and protectionism, where during this period, inward 
looking will be the driver that further enhances governance and human capital empowerment in each country.

The implementation of inward looking policies will not subside the assertiveness of major players, especially China. Following U.S. protectionism, China has become more assertive in its leadership around the world, following its recovery after controlling the spread COVID-19. China's behaviour should not be interpreted as invasive. The country behaves as an ascending power, since IR scholars have coined great powers rivalry era and power transitioning theory to explain the relationship between the U.S and China. As an ascending power, China will do whatever it takes to expand its influence and presence around the world. It manifests its might as well as its assistance to other nation states. China has assisted Italy and some European countries by providing healthcare instruments to fight the virus. Italy had claimed the absurdity of receiving foreign help outside of the European Union. In terms of national security, China's presence can be felt throughout South China Sea as they have deployed military patrols. Turkey, although struggling with internal plight against COVID-19, continues to provide foreign aids to other neighboring countries.

Reversal of hyper-globalization should be channeled to the enhancement of regional effort and subject-based regional integration. ASEAN integration should be enhanced by all member countries since the impacts of globalization can be felt around the world. Intra-trade and political cooperation should be promoted and fully embraced by member countries. This would lead to ASEAN exponential productivity. ASEAN should focus on technological developments to increase communication across all member states.

From the perspectives of geo-economic theory, various studies have been carried out to examine China's role within the international politics and economy. President Xi Jin Ping's leadership is guided with visions of "Chinese Dream" and "Peaceful Development" when projecting Chinese assertiveness to the global outlook (Brown, 2017 and Beeson, 2018). Geo-economics posits that modern national states craft is no longer a zero-sum gain, but the competition focuses on leveraging relative advantage over other states in the international scene. Luttwak (1990), who coined the term geo-economics, has been redefining this term by analyzing China's growing ascendency in the world. It is believed that interconnectivity of trade volume and business prospects between Malaysia and China has further deepen the grip of the economic superpower in Malaysia.

The U.S. believes that China's geo-economics results to an unequal equilibrium with trade and military power projection. In their National Defense Strategy 2018 report, Mattis, in response to China's geo-economics practices which are in line with its military assertiveness, had stated that:

"China is leveraging military modernization, influence operations, and predatory economics to coerce neighboring countries to reorder the Indo-Pacific region to their advantage. As China continues its economic and 
military ascendance, asserting power through an all-of-nation long-term strategy, it will continue to pursue a military modernization program that seeks Indo-Pacific regional hegemony in near-term and the displacement of the United States to achieve global preeminence in the future." (pp.1-2)

The assessment carried out by the U.S. authorities suggested that China's active engagement is beyond hypothetical thoughts. Nationalism and protectionism are reactionary measures to COVID-19, but it will not halt China's grand strategy. Therefore, Malaysia should bode well into this strategy and observe the geo-economics strategy employed by China to leverage its national interest.

The report also highlighted China's geo-economic endowment, whereby BRI member countries "could develop economic dependence on Chinese capital, which China could leverage to achieve its interests" and "consecutively used to deter opposition to China's way of managing sensitive issues" (Department of Defense, 2018: 1).

The NDS 2018 report, under the pretext of "peaceful development", suggested that China conducts its geo-economics strategy, which is described by Blackwill and Harris (2016) and Norris (2016), as the "means to advance its interests and enhance its global role by integrating hard infrastructure development with trade and financial architecture" (Department of Defense, 2018: 51).

Post COVID-19 will also witness a reversal of hyper-globalization process. As this has being undermined by geo-economics theory, Malaysia should approach such reversal with refined strategies that promote multilateralism and regionalization. As a founding member to ASEAN's establishment in 1976, Malaysia has always played a role in the institutional building of ASEAN. However, Mohamed Pero and Ahmad Apandi (2018) had highlighted that the role of Malaysia has not received much appraisal by regional studies and literature. The non-interference policy would not be able to guide the pro-active commitment of member states, including Malaysia. However, in the past decade, Malaysia has demonstrated considerable political will to support regional initiatives in Southeast Asia. Malaysia has continued to champion socio-cultural development by advocating ASEAN Humanitarian Aid Mission. Malaysia deployed assistance post-natural disasters in Acheh and Jogjakarta, restored peace in Mindanao, and recently had taken a strong stand for the Rohingya communities. In the recent ASEAN meeting, Malaysia communicated its aspirations and role to re-define the ways regional setting should function in times of a pandemic.

In its proposal, ASEAN COVID-19 Economic Recovery Plan was devised to provide and maintain social safety nets, food security and education. The three main priorities listed would be an effective long-term measure to address the effects of the COVID-19 pandemic, and other imminent crisis in the future. On its immediate goal, the Recovery Plan should be implemented to equip ASEAN's 600 million population by focusing on preserving connectivity, and ensuring smooth flow of medical supplies, good and essential services. 
Both measures would raise the level of regional preparedness when facing emerging regional landscape. Malaysia had also realized that its country's survival is also dependent on the well-being of its neighbours. As ASEAN countries are inter-connected with population mobilization, capital funds, and business, the region could not afford to allow one of its members to succumb to the negative impacts of the pandemic. The inward looking on regional capacity is believed to be a cushion against the trade war and pandemic worldwide.

Malaysia has continued to champion regional diplomacy. Its battle against the pandemic has raised its reputation in the eyes of ASEAN countries. Malaysia must seize its moment by asserting a balanced leadership into the region. ASEAN needs a constructive and responsive leader, despite being known for its non-interference policy. The COVID-19 pandemic could be a preliminary avenue for Malaysia to insert its active role to ensure ASEAN becomes more prosperous and harmony is maintained.

COVID-19 re-orientates human communication. The argument of new wave of technology emerges strongly through online meetings, which can be conducted comfortably at all locations. Teaching and learning in universities have become completely virtual, where students have to learn from home. From the virtual conference of ASEAN leaders dated April $14^{\text {th }} 2020$, the new wave of technology has reshaped human interaction at the international level digitally. Leaders could meet on an official platform without ever being present. Human communication is the strength of human sustainability in the modern world, regardless of crises and barriers.

New wave technology also advocates renewable energy. When oil price plummeted negatively on April $20^{\text {th }} 2020$, oil is no longer considered a valuable commodity for trade. There are people who have doubts on whether oil would be deemed important after the next 10 years. Instead, as digitalization proceeds around the globe that are backed with data, renewable energy will be the defining wealth in the future. Malaysia should project sustainability (by new wave technology) to the world, especially to the region. According to the preamble of the APEC 2020 in Kuala Lumpur, Malaysia believes that 'human capital growth must be in line with the new wave of technology'. Once again, Malaysia has the opportunity to leverage the idea to its ASEAN colleagues.

In November 2020, Malaysia would organize and host the Asia Pacific Economic Forum. Based on the conference slogan, 'Optimising Human Potential towards a Future of Shared Prosperity', Malaysia advocates on the recap of the basics of any development agenda i.e. human resources. Human Resources (potential) must be leveraged to fight imbalances of trading practice between blocks and economic power. Human resources of the $21^{\text {st }}$ century require cultivation towards a working ecosystem within the society sphere on advanced technology that suits the change of economics nature. Such change requires mastery of digitalization, robotics, artificial intelligence, data analysis, and advancement of automation. This must be a concerted effort between all regional players, whereby Malaysia must aspire to lead the process. According to APEC Secretariat Hairil Yahri Yaacob, 'Malaysia will 
provide the leadership in order to come up with a new vision post 2020 for APEC' (Ram, 2020)

Such leadership role is timely, especially since the region (and the world) has implemented nation lockdowns. People are pushed to the edge, and must reduce socializing and doing business. This halts the human globalization that calls for a change in the norm to accommodate the incoming scenarios. As rightly pointed out, "it is just that we live in an era when issues such as digital economy, digital technology, and sustainability and inclusivity are very important, because these matter to people' (ibid, 20220).

\section{Imminent Focus to Succeed in the Realm of Global Uncertainty.}

\section{Political Security}

Since 2008, Malaysian politics lacks a unified coordination, unlike the past Governments that governed with a strong majority. 2/3 majority is no longer becoming the trend, instead it is obtaining the simple majority (140/222 in 2008, 133/222 in 2013) (SPR, 2013a). This results to a differing opinions on national policies, which is aimed to leverage the objectives of the nation in the years to come. Prior to the $14^{\text {th }}$ General election, Malaysia revamped its Vision 2020 to Transformasi Nasional (National Transformation Plan) TN50. The Framework focuses on the country's operation towards 2050, including implementing some action plans along the way. Unfortunately, the 2018 political tsunami had unsanctioned the TN50, by the new government.

Democracy allows the formation of government by the people. However, Malaysian politics is still within partisan ideology, and is not looking at a national agenda from the country's perspective. The TN50 was scrapped because it was framed as a product of 'Barisan Nasional', instead as a measure to develop the country. Unlike 'Wawasan 2020', which was framed as a national agenda that drives all actors, TN50 was posited as the BN's political agenda. Since the new government would not recognize the framework, hence, the framework was abandoned.

Malaysia's Foreign Policy requires political security to triumph in the global world. It should not be seen as the government's isolated agenda, but must be framed as a national agenda. Political security is needed to synergize political actors, civil servants and Malaysian diplomatic players to have the same objectives for the development of the country. The Kuala Lumpur Summit 2019, though was an initiative by 'Perdana Foundation' and then Prime Minister Mahathir Mohamed, had indirectly sidelined the Organization of Islamic Countries (OIC). This certainly had implication to Malaysia's relations with other Islamic countries, like Saudi Arabia, UAE, Indonesia and others.

\section{APEC}

Malaysia hosted the APEC 2020 in a very untimely situation. Coupled with oil shock crisis and COVID-19, the world economy was put to a halt, and had affected all countries. Cities 
were put into a lockdown, ceasing all economic activities throughout the region. Therefore, the APEC 2020 is estimated to look into the gravity of the lockdowns, and suggests measures that aim to revamp the economy. Malaysia began the APEC meeting by suggesting themes that needed to be discussed by all members such as basic necessity and human capital for shared prosperity.

APEC should be used as a platform for Malaysia to project the concerns of the developing countries. Malaysia should utilize this opportunity to host and establish its power to lead the discussions on the suggested themes. APEC's message should be well received by member countries, and members countries are expected to implement national measures to enhance human capital and to achieve shared prosperity. As a country that currently fares better in curbing the spread of COVID-19, Malaysia must take the opportunity to influence the world on the effective mechanisms that could help address the pandemic. The halting of economies that follows will bring about greater complications to nation states around the world.

The repercussion of COVID-19 would require the full attention of all countries and its population. The impact will not be easy to handle, although specific austerity plans have being launched. In line with viewpoints of Samha Malik, from the London School of Economics, national measurements could not be succeeded without multilateral cooperation by other states. APEC is one of the organizations that could aid cooperation.

\section{ASEAN (ASEAN COVID-19 Economic Recovery Plan)}

ASEAN remains one of the most important organizations for the Malaysian Ministry of Foreign Affairs. It should not be abandoned, regardless of the increased bilateral partnerships with other powerful nations. However, ASEAN has been regarded as an ineffective organization to deal with regional crises. By justifying its non-interference policy as the main reason for its inactive participation, ASEAN has passed many opportunities to foster member states cooperation throughout the crises. However, the COVID-19 pandemic poses a new opportunity for greater cooperation, if all political wills are merged and transformed into viable actions.

Malaysia proposed the ASEAN COVID-19 Economic Recovery Plan that focuses on health care, social needs of welfare, and education. This proposal should be accepted by ASEAN member states as a sustainable measure to address the issues that may arise post COVID-19. Positive developments have been shown through the Joint Statement of the ASEAN Tourism Ministers on Strengthening Cooperation, which aims to revitalize ASEAN Tourism (2020). Seven agreements have been endorsed in the ASEAN Meeting to address the aspects of preparation and operationalization post COVID-19 that are aimed to revitalize the ASEAN economy. The Joint Statement is presented as follows:

1. "Foster ASEAN coordination in expediting information exchange on travel related health and other necessary measures undertaken by ASEAN Member States to control the spread of the COVID-19 outbreak through the enhanced 
operation of the ASEAN Tourism Crisis Communication Team (ATCCT), with a view to providing timely and reliable information for inbound and outbound travelers and tourism operators throughout this region"

2. 'Intensify ASEAN's National Tourism Organisations'(NTOs) collaboration with other relevant ASEAN sectors, especially in health, information, transport and immigration, as well as with ASEAN's external partners, relevant international organisations and the international community, to jointly implement measures and build on each other's platforms to promote a comprehensive, transparent and early response to mitigate and alleviate the impact of COVID-19 and future crises;",

3. "Enhance closer cooperation in the sharing of information and exchange of best practices among ASEAN Member States as well as with ASEAN Dialogue Partners on the responses to the crisis, communications readiness, connectivity coordination, national relief efforts and measures to support the tourism sector, as well as capture key learnings in a post-crisis review report for ASEAN Member States 'reference to better manage future pandemics or crisis; ",

4. "Implement clear policies and measures to bolster confidence among domestic and international visitors to Southeast Asia, including the development of clear standards and guidelines for a safer and healthier work environment to protect our workers and communities in the hospitality and tourism-related industries, destinations and establishments in ASEAN Member States; ’”

5. "Support the development and implementation of a post COVID-19 Crisis Recovery Plan without undermining efforts to safeguard public health, which includes, but not limited to, building up ASEAN tourism capabilities, engaging with industry stakeholders to instill business and consumer confidence, exploring creative and innovative solutions to stimulate the tourism sector especially through the use of digital technologies, ensuring top of mind recall of the region in our marketing efforts and joint tourism promotion programmes with the goal to advance ASEAN as a single tourism destination;"

6. "Expedite both micro- and macro-economic policies, among others, providing technical support and financial stimulus, tax alleviation, capacity and capability building, especially digital skills, for travel and tourism stakeholders, with special emphasis on micro, small and medium enterprises (MSMEs), vulnerable groups and other affected communities;" and

7. "Pursue cooperation with ASEAN Dialogue Partners, relevant international organisations and industry stakeholders to build a resilient and prepared Southeast Asia to effectively implement and manage sustainable and inclusive tourism in the aftermath of a crisis" (ASEAN, 2020). 
Based on the summary of the seven agreements that have been endorsed by the members, ASEAN countries must establish a coordinated framework to boost ASEAN economy, through the tourism industry. This includes the sharing of data and knowledge management system that are employed to address the COVID-19 pandemic. Policy recommendation are focused on changing these joint statement into tangible actions. ASEAN should take responsibility and participate on international affairs to ensure that its aims are met. Past examples have highlighted poor coordination among member states when regional crises emerge. This is due to the fact that previous joint statement lacked any measurable analysis which resulted to the lack of active approaches undertook by member states.

The main objectives established under the seven agreements are generally achievable. Member countries should adopt the agreements and offer capacity measurements to achieve the objectives established in all the statements. This is important to ensure that the agreements are not merely joint-statements with no action taken. Since the start of the pandemic, various inter-governmental meetings have been held to relay information to member countries' on the issues that were caused by it. The meeting between State leaders' on April 14 $4^{\text {th }}, 2020$, followed by the Joint Statement of ASEAN Tourism Ministers are good examples. However, ASEAN should move away from the stereotypes to solve regional issues. The following months should be carefully observed to evaluate ASEAN's regional measures in addressing the impact of COVID-19.

\section{Conclusion}

This study aims to explore the current dynamics of world politics in order to posit Malaysia's Foreign Policy. Two major incidents were highlighted to provide insights on major implications that could change the world. The US-China Trade War and COVID-19 pandemic have both impacted world economy severely, which requires the establishment of new dynamics (re-orientation) at the global level. Since 2018, Malaysia has established a general framework of its foreign policy, and is known as Change in Continuity. The framework retained the fundamental principles of Malaysia's foreign policy, but require a different tactical approach to achieve its new objectives. Therefore, this study examines the practical aspect of the framework, and its incorporation into the current world dynamics. This study had employed the Situational Analysis methodology to understand the world dynamics, and subsequently examine the applicability of Change in Continuity framework to project Malaysia's interest. This is pertinent in ensuring Malaysia sticks to its fundamental principles, especially when initiating changes in the region and around the world. Malaysia still plays a significant role in international relations, as the country has joined various multilateral organizations, including ASEAN and APEC 2020. Malaysia had the opportunity to host the APEC 2020, which provided tremendous leverage for Malaysia to represent the developing countries' interest to address the economic recession and pandemic outbreak in the region.

The objective this study is to examine Malaysia's leadership in APEC 2020, and its efforts to diffuse the tension between the U.S. and China. Malaysia needed the support of other strong 
developing states to reaffirm its stand during the 2020 Conference. As this was seen to be a good opportunity, Malaysia must ensure that APEC would consider the implementation of the themes established during the meeting. Either through conventional summit or virtual meeting, Malaysia must ensure that all member countries employ the themes and begin to construct domestic measures to regulate human capital development in member countries. Every single citizen are inter-connected with one another, and no one should be left behind if one wants to succeed. The new normalcy on states behavior in international relations is not strictly on inward looking of national interest, but an umbrella outlook to on the surrounding nations that would help create a workable system that could benefit all. This is definitely a critical time to observe Malaysia's approach to establish measures for the benefit of its people and the region in the post-pandemic.

\section{Acknowledgement}

This research has not received any specific grant from any funding agency.

\section{References}

Andrews, Kate. (2020). Will Coronavirus push globalisation into reverse? The spectator, United Kingdom, March 7 2020, accessible at https://www.spectator.co.uk/article/ will-coronavirus-push-globalisation-into-reverse (accessed September 7th, 2020)

APEC Secretariat (2020). Gathering in Putrajaya opens year of optimising human potential. Asia-Pacific Economic Cooperation, accessible at https://www.apec.org/Press/ News-Releases/2020/0219 SOM

Beeson, M. (2018). China rises, America falters, and Geo-economics rears its head, war on the rocks, accessible at https://warontherocks.com/2018/08/china-rises-americafalters-and-geoeconomics-rears-its-head/

Blackwill, R. D., \& Harris, J. M. (2016). War by other means. Harvard University Press

Berger, B. (2018). Malaysia's Canceled Belt and Road Initiative Projects and the Implications for China, The Diplomat, August 27, 2018. https://thediplomat.com/2018/08/ malaysias-canceled-belt-and-road-initiative-projects- and-the-implications-forchina/

Browne, A. (2015). Can China be contained? The Wall Street Journal, accessible at https:// www.wsj.com/articles/can-china-be-contained-1434118534

Cheng, C. (2019). Is Malaysia benefitting from the U.S. - China trade war?, East Asia Forum, August $5^{\text {th }}$, accessible at https://www.eastasiaforum.org/2019/08/05/is-malaysia-benefitting-from-the-us-china-trade-war/

Cousin, M., \& Orlik, T. (2020). Here are the losers from US-China trade agreement. Bloomberg, accessible at https:/www.bloomberg.com/news/articles/2020-01-22/ here-are-the-losers-from-u-s-china-trade-agreement-map

Department of Defense (2018). Military and security developments involving people's republic of China. Department of Defense, United States, accessible at https://www. hsdl.org/?view\&did=814130 
Elina, Noor. (2019). Foreign and security policy in the New Malaysia, Lowy institute, accessible at https://www.lowyinstitute.org/publications/foreign-and-securitypolicy-new-malaysia

He, Huifeng. (2020). China's inward-facing "Dual Circulation" strategy leaves many wondering where domestic demand will come from. South China Morning Post, accesible at https://www.scmp.com/economy/china-economy/article/3100482/ chinas-inward-facing-dual-circulation-strategy-leaves-many (7th September, 2020)

Jabatan Perdana Menteri (2020). Ucapan Perdana Menteri Malaysia ke-8, pakej rangsangan ekonomi prihatin rakyat Malaysia, accessible at https://www.pmo.gov. $\mathrm{my} / \mathrm{ms} / 2020 / 03 /$ teks-ucapan-perutusan-khas-pakej-rangsangan-ekonomi-prihatinrakyat-prihatin/ (June 27, 2020).

Joint Statement of the ASEAN Tourism Ministers on Strengthening Cooperation to Revitalise ASEAN Tourism (2020). Association of Southeast Asia Nations, Jakarta, accessible at https://asean.org/storage/2020/04/ENDORSED-Joint-Statement-of-theASEAN-Tourism-Ministers-on-COVID_19-29Apr20.pdf

Kapustina et. al,. 2020. U.S. China Trade War: Causes and Outcome, SHS Web of Conferences, 73(1): 01012.

Keputusan Rasmi Pilihanraya Umum ke - 12 (2008). Suruhanjaya Pilihanraya, accessible at http://semak.spr.gov.my/spr/laporan/5_KedudukanAkhir.php depar

Md. Khalid, K. (2009). Malaysian Foreign Policy Orientation and Relations in the PostMahathir Years, University of Malaya, accessible at http://eprints.um.edu.my/10906/

Lee, H. G. (2018). In Experts: US-China Trade War May Have Negative Impact on Malaysia. Investor, accessible at https://klse.i3investor.com/blogs/savemalaysia/2018-08-07story-h1454419400-Experts_US_China_trade_war_may_have_negative_impact_ on_Malaysia.jsp

Leifer, R. (1989). Understanding organisational transformation using a dissipative structural model, Human Relations, 42(10), pp. 899-916.

Luttwak, E. (1990). From geopolitics to geoeconomics. National Interest, 20(20), pp. 17-24.

Mahbubani, K. (2020). Has China Won? Public Affairs, New York, NY 10104.

Malaysia External Trade Development Corporation (2020). Summary of Malaysia's Monthly Trade 2020, accessible at http://www.matrade.gov.my/en/malaysian-exporters/ services-for-exporters/trade-market-information/trade-statistics/28-malaysianexporters/trade-statistics/5084-summary-of-malaysias-monthly-trade-2020 (August $\left.8^{\text {th }}, 2020\right)$

Mohamed Pero, S. D., Ahmad, Apandi. (2018). Malaysia's leadership role in ASEAN: An assessment, Journal of International Studies, 14, 65-79.

Mottain, M. (2019). Slowing Private Investments Poses Risk to Economy, Yunus R. \& Ong, R. The Malaysian Reserve accessible at https://themalaysianreserve.com/2019/11/18/ slowing-private-investments-poses-risk-to-economy/

Ministry of Foreign Affairs, Malaysia (2019). Foreign policy framework of the new Malaysia Change in Continuity, p. 27.

Nasim, S., \& Sushil. (2011). "Revisiting organizational change: Exploring the paradox of managing continuity and change." Journal of Change Management 11(2), 185-206. 
Norris, W. J. (2016) Chinese economic statecraft: Commercial actors, grand strategy, and state control, Cornell University Press

NST Online (2018). Dr. Mahathir at $73^{\text {rd }}$ UN general assembly, New Straits Times, September 29, 2018, accessible at https://www.nst.com.my/news/nation/2018/09/415941/ speech-text-dr-mahathir-73rd-un-general-assembly

NST Online (2019). Dr. Mahathir at 74th UN general assembly, New Straits Times, September 28, 2019, accessible at https://www.nst.com.my/news/nation/2019/09/525269/dr-msfull-speech-text-74th-unga

Povera, A., \& Goh, P. P. (2020). China suspending tour groups will hit Malaysia hard, says Matta President, New Straits Times, accessible at https://www.nst.com.my/news/ nation/2020/01/560062/china-suspending-tour-groups-will-hit-malaysia-hard-saysmatta-president (August 8th, 2020).

Prime Minister Office, (2018). Keeping Asia Open - How to Achieve Prosperity and Stability, Speech delivered at the $24^{\text {th }}$ International Conference on the Future of Asia, 11 June 2018, https://www.pmo.gov.my/2018/06/keeping-asia-open-how-to-achieveprosperity-and-stability/.

Ram, B. Suresh. (2020). APEC Aiming For Its Shared Prosperity Agenda To Be Translated Into Work Plans, New Straits Times, accessible at https://www.nst.com.my/news/ nation/2020/02/567327/apec-aiming-its-shared-prosperity-agenda-be-translatedwork-plans (July 7th, 2020).

Suruhanjaya Pilihan Raya (SPR) (2013a), 'Statistik keseluruhan bagi Parlimen PRU13', PRU13, http://keputusan.spr.gov.my/\#home

Silver, C. (2020). The top 20 economies in the world ranking the richest countries in the world. Investopedia, accessible at https://www.investopedia.com/insights/worldstop-economies/ (September $7^{\text {th }}, 2020$ )

Tan, H. L. (2020). China's say its economy grew 6.1\% in 2019, in line with expectations. China economy in CNBC, accessible at https://www.cnbc.com/2020/01/17/chinagdp-for-full-year-and-q4-2019.html (September 7, 2020)

Vogel, P. (2020). Nationalism the even greater risk of the COVID-19 Crisis?, IMD Business School for Management and Leadership Courses, accessible at Vogel $2020 \mathrm{https}: / /$ www.imd.org/research-knowledge/articles/Nationalism-the-even-greater-risk-ofthe-COVID-19-crisis/ (August 15 ${ }^{\text {th }} 2020$ )

Worldometer, (2020). COVID-19 coronavirus pandemic. Accessible at https:/www. worldometers.info/coronavirus/ 